\author{
VÉGH ANDOR \\ (Pécs, Magyarország)
}

\title{
Mađarsko stanovništvo u NDH - brojčano stanje i proces nestajanja u periodu između 1941. i 1945.
}

Sažetak: Mađari na području Hrvatske su ona manjinska grupa u Karpatskom/Panonskom bazenu, uspoređujući sa Mađarima drugih susjednih država, koja je nakon 1918. godine izgubila najviše svojih pripadnika dijelom iseljavanjem, dijelom asimilacijom. Najintenzivniji nestanak ove manjinske grupe sa hrvatskih područja su decenije među popisima 1931 i 1948 godine. U ovom radu se bavimo pitanjem iseljenja i društvenih odnosa Mađara unutar granica Nezavisne Države Hrvatske (NDH) i pod upravnim područjem Narodnooslobodilačke Vojske Jugoslavije (NOV). Pomoću arhivske građe pokušavamo rekonstruirati one društvene okolnosti ratnih godina koje su prouzročile iseljavanjem velikog broja pripadnika ove zajednice.

Ključne riječi: Mađari u Hrvatskoj, Drugi svjetski rat, Nezavisna Država Hrvatska - NDH, Narodnooslobodilačka Vojska Jugoslavije, iseljenje

\section{Uvod}

Poslije 1918. pitanje mađarskog stanovništva izvan post-trijanonskih granica Mađarske može se smatrati jednim od temelja mađarske vanjske politike i međudržavnih odnosa u Panonskom bazenu. Ovo vrijedi i za hrvatskomađarske odnose u XX. stoljeću neovisno o činjenici da su se ovi izvan jugoslavenskih ograničenja mogli formirati jedino u periodu NDH (1941.1945.) kako i poslije 1991, osamostaljenjem Hrvatske. Pitanje Mađara u Hrvatskoj je nadalje važno zbog više činjenica. Ova je grupa bila a dijelom i do dan danas jeste etnografski i društveno složena zajednica koja se od predosmanskih vremena do XIX. stoljeća postepeno formirala u društveno i vjerski (konfesionalnu) heterogenu, u prostoru od juga Baranje do Bilogore i Međimurja raštrkanu mađarsku zajednicu. Vjerojatno tome zahvaljujući ova grupa Mađara je zabilježila najveći pad u broju zajednice između 1910. i 1950ih godina. Najveći intenzitet nestajanja zabilježen je 1940-ih godina, zahvaljujući Drugom svjetskom ratu i poraću na prostoru bivše NDH i Jugoslavije.

U ovom kratkom radu pokušavam preciznije odrediti društvene odnose, stanje kao i tokove raseljavanja Mađara s područja Hrvatske (NDH) koncentrirajući na područja Zapadne-Slavonije i Bilogore, gdje je spomenuto nestajanje bilo najintenzivnije. Istraživanje sam vršio u Hrvatskom državnom arhivu u Zagrebu, nadalje u ispostavama Državnog arhiva u Osijeku i 
Bjelovaru 2014 i 2015 godine. Tako se ovaj rad temelji prvenstveno na još ne ili samo djelomično objavljenim dokumentima iz datog povijesnog perioda.

\section{Statistike, popisi, brojke}

Najveći nedostatak u istraživanju brojčanog stanja i teritorijalne rasprostranjenosti mađarske zajednice na području NDH predstavlja nedostatak popisa na području Kraljevine Jugoslavije 1941. Prema današnjem našem znanju taj popis je bio započet 1941, no zbog raspada države u travnju 1941. ona se neće provesti a ni sakupljeni podaci neće biti obrađeni ili objelodanjeni. Jedini izuzetak predstavlja područje Banata na sjeveroistoku države gdje će se pod njemačkom upravom doći do sakupljanja i obrade podataka popisa iz 1941. Ne možemo biti sigurni da ovi statistički podaci nisu postojali za područje $\mathrm{NDH}$, ali sam tijekom arhivskog istraživanja uočio da se javna uprava i statistička služba NDH koristi sa statističkim brojkama iz 1931. (drugog popisa na području Kraljevine SHS) preračunatim za 1941 godinu ${ }^{1}$, mada se u svakom detalju trudila izbjeći pravni ili bilo koji kontinuitet s jugoslavenskom državom između 1918. i 1941.

Središnja je uprava više puta uredbama pokušavala primorati županijske upravne organe za dopunu statističkih nedostataka, prvenstveno o demografskom stanju države a naročito o stanju mađarske zajednice. To je bilo nužno naročito zbog toga što nakon kolonizacijskih procesa ${ }^{2}$, iseljavanja i spontanih bježanja stanovništva, pogotovo poslije jeseni 1942. država nije imala realnu sliku o stanju stanovništva na području istraživanja ${ }^{3}$. Nažalost, unatoč svim pokušajima jedinstveni popis mađarskog stanovništva nije izvršen premda je Ministarstvo unutarnjih poslova NDH (MUP NDH) pokrenula popis Mađara 1942. s ciljem organiziranog iseljavanja ili zamjene s hrvatskim stanovništvom Mađarske ${ }^{4}$. Tragove ovog popisa možemo naći u kutiji MUPNDH-UMT-Kut. br. 1 gdje se opisuje opće stanje na području velike župe Livac-Zapolje s etničkim i vjerskim podacima za kotar Daruvar.

\footnotetext{
${ }^{1}$ HRD-HDA-Državna statistika, Kut.2,3

2 O kolonizaciji na području Slavonije za vrijeme postojanja NDH detaljnije vidi: BALTA 2001.

${ }^{3}$ MUP-NDH-UMT-kut.1378/1944, HDA-MUP NDH 1, U.M.T. 1324/43, U ovim dokumentima je već vidljivo da neka, uglavnom brdska naselja već nisu pod kontrolom NDH, već partizanskih četa.

${ }^{4}$ O planu zamjene stanovništva između dvije države dogovori su započeti već 1941 . godine, odmah nakon osnivanja NDH, no pogoršavanjem međudržavnih odnosa zbog pripajanja Međimurja Mađarskoj ovaj plan je propao. Detaljnije o planu iseljenja Mađara, tj. o zamjeni stanovništva NDH-Mađarska vidi: KARAKAŠ 2012; SAJTI 1987.
} 
Slika br 1 Popis stanovništva po vjerskoj i nacionalnoj pripadnosti u Kotaru Daruvar iz 1942. ili 1943. godine, općine Veliki Bastaji i Dežanovac

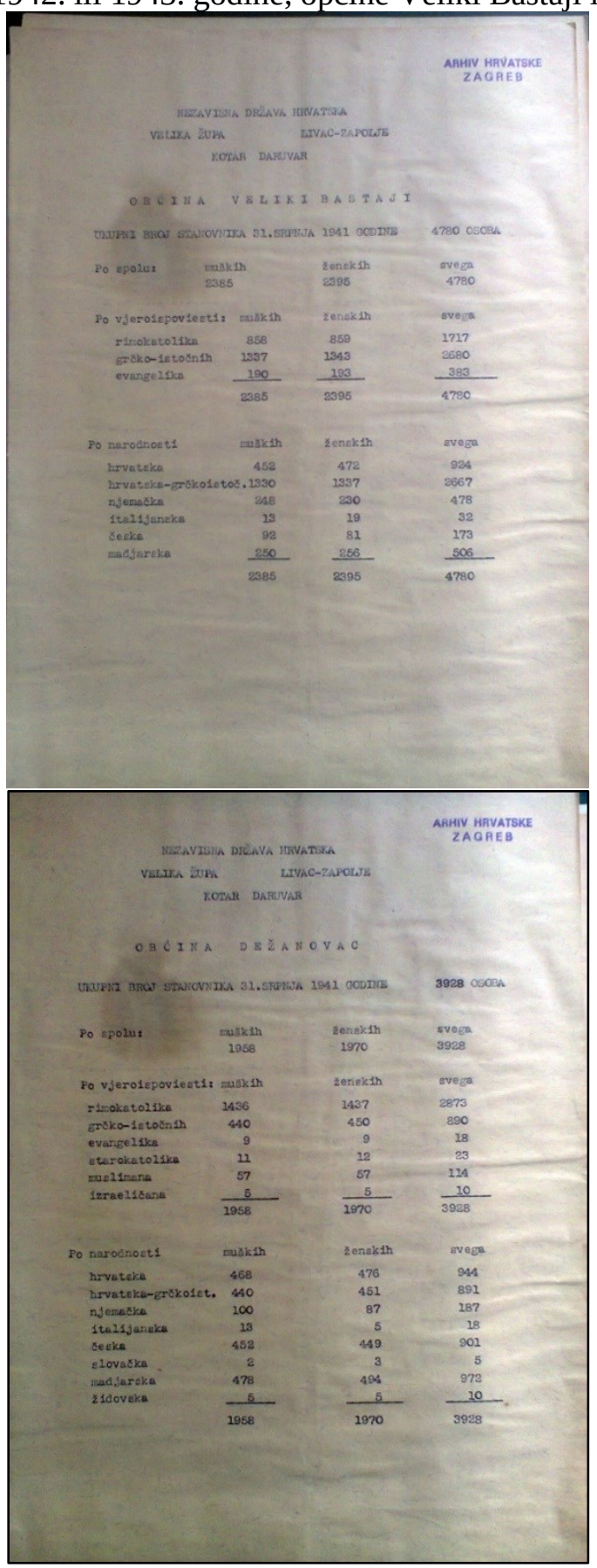

Izvor: HDA Zagreb MUP-NDH-UMT KUT. br. 1 
O brojčanom stanju Mađara na području NDH najkompletniji podaci se nalaze u jednom općem izvješću, koje je datirano 6. rujna 1952. i nalazi se među dokumentima Saveza kulturno-prosvjetnih društava Narodne Republike Hrvatske (osnovan 27. studenog 1949. u Osijeku) u Državnom arhivu u Osijeku. Ovi podaci se odnose na godine 1940-41-42-43., a sadrže informacije o brojčanom stanju mađarske zajednice i o njihovim školama u pojedinim naseljima u Hrvatskoj unutar SFR Jugoslavije (uključujući samo zapadni Srijem). Brojke su samo procijenjene a ne rezultati točnog popisa stanovništva, a odnose se samo na Mađare. Iz dokumenta se daje naslutiti da se radi o internoj listi Mađarske kulturne zajednice (MKZ) koji je nastao za internu uporabu ili kao neka baza podataka za vrijeme planiranog preseljenja. Manje mađarske zajednice se ne spominju, najmanja zajednica je spomenuta u Mikleušu u slatinskom kraju, a u Zapadnoj Slavoniji nisu istaknute ni veće zajednice. Na kraju dokumenta se ističe da se radi o naseljima gdje je MKZ imao svoju organizaciju a podvučena (u našem prijepisu naselja istaknuta debelim i kosim slovima) nisu imala organizaciju ili se organizacija Zajednice raspala zahvaljujući djelovanju Strelastih križeva (Nyilas keresztesek) u navedenim godinama popisa. Isključivo iz ove tablice ne možemo točno ustvrditi ali pomoću ostalih izvora može se zaključiti da je djelovanje Strelastih križeva bilo najaktivnije u Srijemu i Istočnoj Slavoniji u okolici Vinkovaca te u ostalim gradskim sredinama.

Tabela br 1. Podaci o brojčanom stanju Mađara u Hrvatskoj između 1940. i 1943.

\begin{tabular}{|l|c|c|}
\hline Naselje & Broj Mađara & Godina podatka \\
\hline Vukovár, Borovo gyár & 900 & 1941. \\
\hline Sr. Čakovci & 800 & 1940. \\
\hline Sotin & 60 & 1940. \\
\hline Tompojevci & 150 & 1940. \\
\hline Berak & 300 & 1942. \\
\hline Slakovci & 60 & 1942. \\
\hline Opatovac & 600 & 1942. \\
\hline Marinci & 600 & 1942. \\
\hline Vinkovci & 400 & 1943. \\
\hline Andrijaševci & 200 & 1942. \\
\hline Rokovci & 50 & 1942. \\
\hline Cerna & 500 & 1942. \\
\hline Retkovci & 200 & 1943. \\
\hline Ivankovo & 200 & 1943. \\
\hline Nuštar & 400 & 1943. \\
\hline
\end{tabular}




\begin{tabular}{|l|c|c|}
\hline Tordinci & 300 & 1942. \\
\hline Antin & 120 & 1942. \\
\hline Markušica & 150 & 1941. \\
\hline Otok & 100 & 1943. \\
\hline Privlaka & 150 & 1943. \\
\hline Babina greda & 100 & 1943. \\
\hline Stari Jankovci & 800 & 1941. \\
\hline Županja & 200 & 1942. \\
\hline Drenovci & 100 & 1942. \\
\hline Brčko és környéke a & & \\
\hline visszatelepítés után & 400 & 1942. \\
\hline Rajevo selo & 100 & 1942. \\
\hline Strošinci & 60 & 1942. \\
\hline Račinovci & 100 & 1942. \\
\hline Osijek & 3000 & $1940-41$. \\
\hline Rétfalu & 1400 & $1940-41$. \\
\hline Tenje pusztákkal & 600 & $1940-41$. \\
\hline Tenjski Antunovac & 600 & 1941. \\
\hline Szőllős & 280 & 1941. \\
\hline Franjindvor és Rudina & 246 & 1941. \\
\hline Laslovo & 868 & 1940. \\
\hline Füzes puszta & 134 & 1940. \\
\hline Kórógy & 1041 & 1940. \\
\hline Ernestinovo és Reiner p. & 116 & 1941. \\
\hline Haraszti & 600 & 1940. \\
\hline Vámosi puszta & 62 & 1940. \\
\hline Vladislavci falu & 600 & 1940. \\
\hline Vladislavci puszták & 400 & 1940. \\
\hline Čepin, Ovčara, Bara & 580 & 1941. \\
\hline Dalj-Planina & 500 & 1941. \\
\hline Aljmaš & 160 & 1941. \\
\hline Erdut & 182 & 1941. \\
\hline Đakovo & 200 & 1941. \\
\hline Selci & 500 & \\
\hline Vrpolje, Čajkovci & 140 & \\
\hline Pridvorje & & \\
\hline
\end{tabular}




\begin{tabular}{|l|c|l|}
\hline Drenje & 300 & 1941. \\
\hline Ivanovci & 660 & 1941. \\
\hline Satnica & 200 & 1941. \\
\hline Viškovci & 100 & 1941. \\
\hline Kašinci-Semeljci & 120 & 1942. \\
\hline Trnava, Podgorje, Breznica & 90 & 1941. \\
\hline Našice & 150 & 1941. \\
\hline Razbojište & 200 & 1941. \\
\hline Podgorač & 60 & 1941. \\
\hline Sušine-Đurđenovac & 200 & 1941. \\
\hline Bankovci & 400 & 1941. \\
\hline Feričanci & 40 & 1941. \\
\hline Zdenci pusztákkal & 300 & 1941. \\
\hline Staro Petrovopolje es környéke & 400 & 1941. \\
\hline Čačinci & 124 & 1941. \\
\hline Humljani & 300 & 1941. \\
\hline Mikleuš & 40 & 1941. \\
\hline Belišće & 500 & 1941. \\
\hline Valpovo & 240 & 1941. \\
\hline Dolnji-Miholjac és környéke & 500 & 1940. \\
\hline Slatina és környéke & 600 & 1941. \\
\hline Starin & 300 & 1942. \\
\hline Čađavica, Lug & 200 & 1942. \\
\hline Sopje, Kapinci & 350 & 1942. \\
\hline Cabuna és környéke & 200 & 1942. \\
\hline Virovitica, Szőllők és Antunovac & 800 & 1942. \\
\hline Suhopolje, Čemernica & 400 & 1942. \\
\hline Gradina és puszták & 200 & 1942. \\
\hline Budakovac, Gaćište, Aladár pa. & 700 & 1942. \\
\hline Novi Gradac, Peščani, Crni Zaton(y) & 600 & 1942. \\
\hline Terezinopolje, Neteča, Zrin & 450 & 1942. \\
\hline Rezovac & 300 & 1942. \\
\hline Požega és környéke & 400 & 1942. \\
\hline Grđevica & 400 & 1942. \\
\hline Poljane & & \\
\hline Dragutinovac és környéke & 00 & \\
\hline
\end{tabular}




\begin{tabular}{|l|c|c|}
\hline Brod és környéke & 600 & 1942. \\
\hline Lipik, Pakrac, Prekopakra & 30 & 1942. \\
\hline Daruvar és környéke & 700 & 1942. \\
\hline Cjepidlaka, Đulovac & 400 & 1942. \\
\hline Šupljalipa & 80 & 1942. \\
\hline Kreštelovac & 450 & 1942. \\
\hline Imsovci & 328 & 1942. \\
\hline Sokolovac, Dežanovci & 122 & 1942. \\
\hline $\begin{array}{l}\text { Gaj, Brekinjska, Goveđepolje, } \\
\text { Poljana, Jamarica }\end{array}$ & 1200 & 1941. \\
\hline Összesen 122 település & 35.363 & - \\
\hline
\end{tabular}

Izvor: Državni arhiv Osijek, Fond spisa Saveza kulturno-prosvjetnih društava Mađara Narodne Republike Hrvatske (kasnije Demokratski savez Mađara u Hrvatskoj), kutija br. 1, Opći spisi $1-609$.

\section{Odnos Mađara i vlasti NDH}

Premda je Mađarska bila prva država koja je priznala NDH (JONJIĆ 2000) granični sporazum između dvije države nikada nije ratificiran, usprkos tome što je bilo više sastanaka hrvatske i mađarske strane u cilju postizanja rješenja. U ovom ozračju rješavanje manjinskog pitanja bilo je zamišljeno provesti „korigiranjem”, prekrajanjem postojećih etničkih granica. Na to je NDH dijelom bila prisiljena - primanjem iseljenih Slovenaca sa slovensko-štajerskih područja koje su bile pripojene Trećem Reichu, a dijelom je to sačinjavalo i njenu rasnu, demografsku politiku - iseljavanje srpskog stanovništva. Već na sastanku Hitlera i Pavelića 6. svibnja 1941. je dogovoreno, da NDH primi 175.000 iseljenih Slovenaca iz Štajerske i Kranjske a da iseli isti broj Srba sa svog područja u Srbiju (JONJIĆ 2000). Slično rješenje se planiralo sprovesti i s Mađarima na području NDH koji su se trebali iseliti u Mađarsku u razmjenu za tamošnje hrvatrsko stanovništvo (A. SAJTI 2010; KARAKAŠ OBRADOV 2012).

U prvoj polovici 1941. nedugo nakon osnivanja NDH Mađarska stupa u kontakt s NDH ciljem da bi se odlučilo o mogućnosti razmjene stanovništva. Hrvatska strana je bila spremna za organiziranje razmjene stanovništva, naselivši Hrvate u domove protjeranih Srba (KARAKAŠ OBRADOV 2012). $\mathrm{Na}$ ovim sastancima oko iseljavanja je također dogovoren transport iseljenih Srba iz Mađarske preko područja NDH, no Pavelić je oštro izjavio da „NDH neće primiti solunske dobrovoljce na svoje državno područje" (KARAKAŠ OBRADOV 2012). Nakon ovih brzih koraka u cilju preseljenja na uzajamnoj osnovi međudržavni odnosi NDH i Mađarske zbog pitanja Međimurja su u znatnoj mjeri pogoršani (SOKCSEVITS 2016b), tako nije došlo do provedbe razmjene stanovništva. 
Nakon jačanja iseljenja Mađara sa područja NDH, koje će se pojaviti od jeseni 1942. paralelno sa sve snažnijom partizanskom djelatnošću sve se više očituje negativni stav ustaške vlasti prema pripadnicima mađarske zajednice u NDH. U više dokumenata možemo primijetiti da su hrvatske vlasti češće pružale pomoć prilikom iseljenja Mađara u Mađarsku. U više navrata je automatski dozvoljeno prelaženje granice Mađarima a također se ništa nije poduzelo protiv spontanih prelaženja izbjeglih pojedinaca i obitelji ${ }^{5}$.

Usprkos tome što su Mađari u NDH u većini dostupnih dokumenata opisani kao lojalni građani države, odnosi državnih vlasti prema njima se ne može nazvati „prijateljskim“ naročito usporedivši s Nijemcima u NDH, čija su naselja često bila organizirana u zasebne općine $\mathrm{s}$ visokom razinom samouprave ${ }^{6}$. Ovaj loš odnos temeljio se na prije spomenutim međudržavnim odnosima, zbog kojih su se Mađari smatrali produženom rukom Mađarske u teritorijalnim pretenzijama. Pored toga i NDH je imala težnje za teritorijalnim proširenjem (LORKOVIĆ 1939) - smatrala je svojim ne samo Međimurje već i Baranju i Bačku - i neovisno što je u onom trenutku to bio politički nedostižan cilj neki vodeći politički krugovi su ova pitanja držala na površini ${ }^{7}$.

Neslaganja i politički sukobi NDH i Mađarske su se najbolje očitovali u postupcima prema mađarskim organizacijama unutar NDH. O tome svjedoči dokument u kojem Mađarska kulturna zajednica (MKZ) traži od MUP-a NDH rješenje za sporove s organizacijom Strelastih križeva kako i za druga organizacijska pitanja - osnivanje novih podružnica, osiguranje slobodnog kretanja svojim zastupnicima itd ${ }^{8}$. Ministarstvo naravno nije stalo ni na jednu stranu u osjetljivom pitanju zavađenih mađarskih skupina, nego je privremeno, ali sa ograničenjem dopustila djelovanje objema organizacijama. S time je zauzela sličan stav kako kod srpskih, no koje nije primjenjivala kod njemačkih civilnih udruga.

\footnotetext{
${ }^{5}$ HRD 1491. OZNA. 03. 01. 2. Mjesečni izvještaj za siječanj 467/44

${ }^{6}$ Tako na primjer Eichendorf - Hrastovac između Daruvara i Kutine je sa svega 748 stanovnika - od toga 737 stanovnika njemačke narodnosti - imalo svoju općinu, dok je u ovom području prosječna općina bila organizirana za 2-3 tisuće duša i za više naselja, zaseoka. Vidi dokument u MUP-NDH-UMT - Kutija br. 1, dokument bez broja.

${ }^{7}$ O tome svjedoče izvješća velikih župana i drugi dokumenti Ministarstva vanjskih poslova NDH HDA, MVP NDH, kut. 6. 3556/1941, HDA, MVP NDH, kut. 6. 11396/41, HDA, MVP NDH, kut. 6. 8655/41

${ }^{8}$ HDA, MVP-NDH, kut. 6. 4758/1942
} 
Slika br 2 Odgovor MVP NDH MUP-u na primjedbe MKZ-a

Okružnicom ministra unutamjih poslova broj 2317-I-A-1942.od 16.0zujlca ovim velikim zupame 1 redarstvenoj oblasti za grad Zagreb - pomenuto jo da Y.K.Z. ni kao jedinica u Zagrebu, a niti kao cjelina noma potvrdjenih pravila u N.D.H. /kao niti njima suprotna organizacija Strielasi Križevi/. Prema tome, a obzirom na zakonske propise koji vriede ga sva drǚtva 1 arž̀avljane u N.D.H. M.K.Z. nije legalno jos̆ prisnata,poř to to ovisi - vanjsko politickim momentima u kojem obujmu, pravima 1 kada de to usliediti, nego je samo

TOLBRTRANA.

Izvor HDA - Zagreb, MVP-NDH, kut. 6. 4758/1942 str 3.

Ovim organizacijama nije automatski odobreno djelovanje osnovano na prijašnjoj registraciji u Kraljevini Jugoslaviji. Na taj način vlasti su pojedine organizacije mogle ograničiti u svojem djelovanju (nemogućnost razvijanja strukture, zasjedanja, slobodnog kretanja predstavnika itd.). Na kraju će od dviju mađarskih organizacija Strelasti križevi biti zabranjeni ${ }^{9}$ a MKZ je u travnju 1942. priznata kao legalna udruga, ali njihovo je djelovanje bilo ograničeno i bilo u stalnom fokusu obavještajnih službi (KASAŠ 1996: 126).

Godišnja sjednica MKZ-a je bila održana (još prije priznanja) 8. ožujka 1942. u Zagrebu, o kojem je zagrebačka policija već peti dan nakon toga u ime MUP izvijestila Ministarstvo vanjskih poslova (MVP NDH) ${ }^{10}$. U ovom dokumentu čiji je potpisnik bio glavni ravnatelj policije članstvo MKZ-a je procijenjeno na 30.000 a povučena je paralela između MKZ-a i njemačkog Kulturbunda (i izvori OZN-e MKZ dosljedno nazivaju mađarskim kulturbundom). Pored ostalog istaknuto je da organizacija ima ciljeve proširenja broja članova i organizacijske mreže i da većina predstavnika ne dijeli prijateljski odnos Janoša Horvata, voditelja društva prema vlastima NDH. U ovom izvješću je također bilo istaknuto da MKZ ima dva državna centra u Zagrebu i Osijeku koji se mogu smatrati ravnopravnima što je interesantno zato što Aleksandar Kasaš u svom djelu Mađari u Vojvodini 1941-1946 navodi da MKZ ima samo jedno državno središte (KASAŠ 1996).

Dobro se očituje situacija i stanje mađarske zajednice i u jednom dokumentu iz Bjelovara koji sadrži opis proslave godišnjice nastanka NDH u Bjelovaru u travnju $1942^{11}$.U ovom opisu se vidi da u svečanom mimohodu nakon državnih oružanih snaga slijedile su njemačke udruge i nakon njih hrvatski civili. Mađarskih udruga nije bilo, premda je njihova uloga i brojčano stanje u to doba bilo značajnije od Njemaca i u gradu i u okolici.

\footnotetext{
${ }^{9}$ Kasnije će se Strelasti križevi ponovo formirati u ilegali pa će zbog toga njihov vođa Gyula Sütő biti protjeran iz NDH, koji će državu napustiti 5. prosinca 1942. kod Savskog Marofa prema Trećem Reichu (na područje današnje Slovenije). HDA MUP NDH UMT kut. 1. 897/1943.

${ }^{10}$ HDA, MVP-NDH, kut. 6. 8102/1942

${ }^{11}$ HDA, NDH Velika Župa Bilogora kut. 1. 17031 - IV-1942
} 
Najznačajnija točka nesporazuma između NDH i mađarske zajednice bila je obavezna vojna služba, pred kojom su Mađari u značajnom broju bježali u Mađarsku. Prema Aleksandru Kasašu MKZ je već u jesen 1941. aktivno propagirala ne prihvaćenje obaveznog vojnog roka Mađara u postrojbama vojske NDH (domobrani), čime su ih posredno nagovarali na bježanje u Mađarsku. U već navedenom dokumentu MVP se zalagalo na primjenjivanje oštrijih mjera prema vojnim neposlušnicima.

\section{Slika br 3 Odgovor MVP NDH MUP-u}

u vezi s ilegalnim prelascima granice vojnih bjegunaca

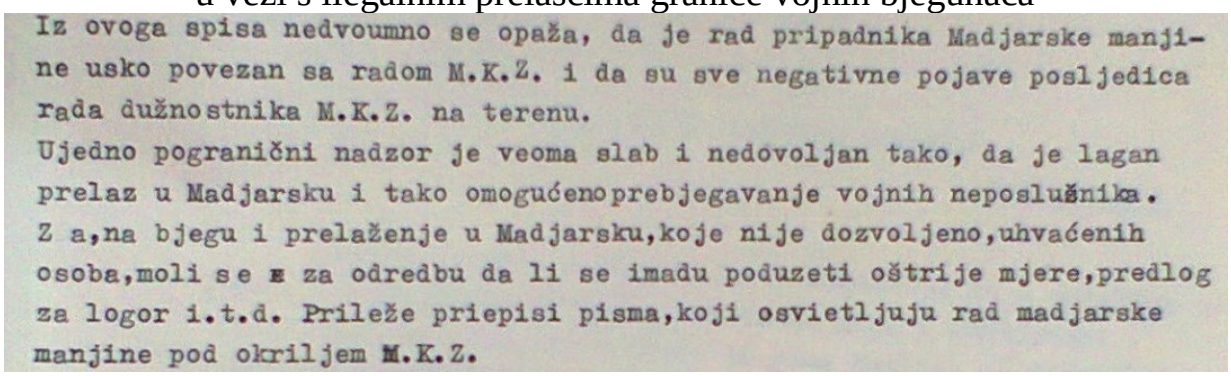

Izvor HDA - Zagreb, MVP-NDH, kut. 6. 4758/1942 str 5.

Mađarska se granica jako slabo čuvala na Dravi i Dunavu, a NDH nije imao dovoljno vojnika u graničarskoj službi da spriječi ilegalno prelaženje, pa su to Mađari iskoristili bježeći pred vojnom službom. Prema nekim dokumentima na istoku Slavonije i u Srijemu bježanje Mađara je bila svagdašnja pojava, naročito na području oko Vukovara, Sotina i Opatovca ${ }^{12}$. Pošto se mađarskohrvatska granica pripajanjem Bačke, Baranje i Međimurje skoro potpuno premjestila na rijeke, područje Repaškog okruga sjeveroistočno od Koprivnice, bila je jedina granica koja se mogla smatrati kopnenom između NDH i Mađarske (REGAN 2003: 282). Ova kratka granična linija, u čijoj neposrednoj okolici je također živjelo Mađara na hrvatskoj strani, time je dobila na važnosti. Iz arhivskih dokumenata se daje utvrditi da su NDH vlasti pribojavale od mađarske teritorijalne ekspanzije $\mathrm{i}$ na tom području ${ }^{13}$, no to nije bilo upozorenje MVP već lokalna informacija MUP-a s terena.

12 HDA, MVP-NDH, kut. 6. 3006-I-A-1942 (dne 22. travnja 1942). U ovom dokumentu krivnja zbog loše čuvane granicu ispod Vukovara - gdje bježe Mađari u većem broju - se svaljuje na nepouzdane elemente među graničnom policijom i ističe se da bi ih valjalo zamijeniti sa pouzdanijim ustašama ili Nijemcima. Vjerojatno u službi na granici su ovdje radili Mađari iz okolnih naselja koji su igrali važnu ulogu u organiziranju bježanja pred vojnom službom.

${ }^{13}$ MVP-NDH-1942 kut br.6 Nr:7359-I-A-1942 
Slika br 4 Izvješće kotarske oblasti o stanju na granici blizu Koprivnice

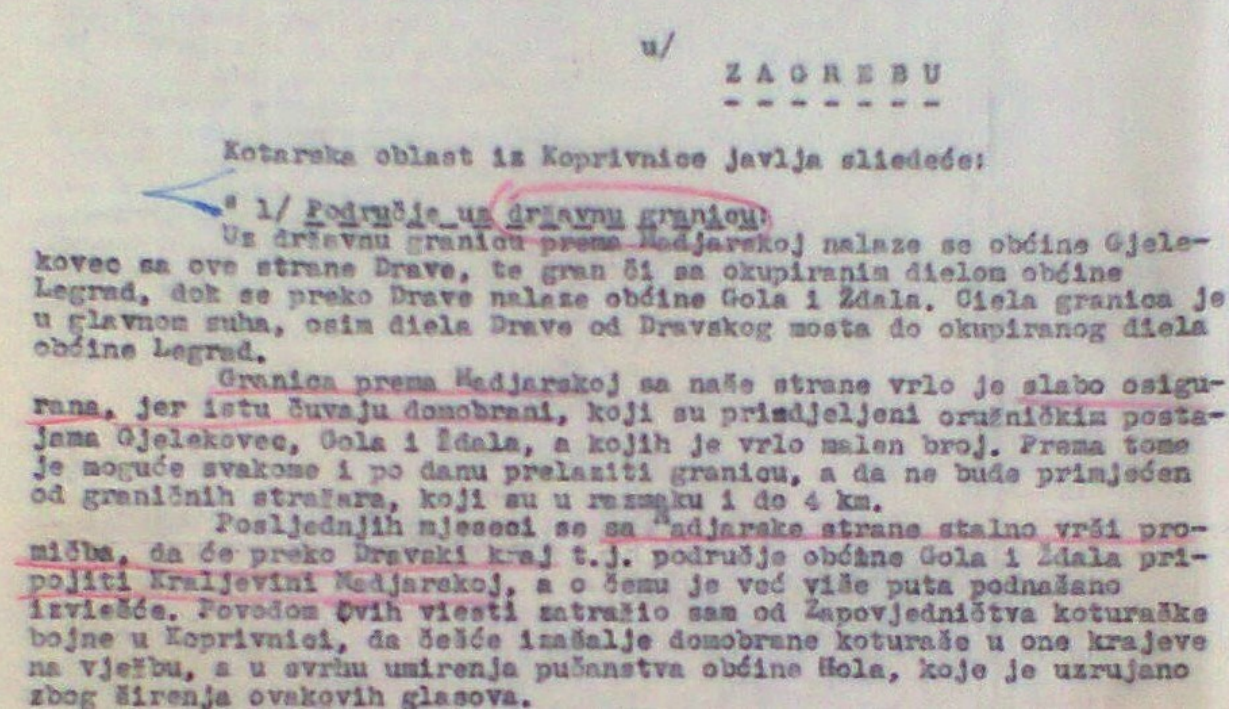

Izvor: MVP-NDH-1942 kut br.6 Nr:7359-I-A-1942

U nastavku dokumenta se analizira stanje među stanovništvom općina sjevernije od Drave - Gole i Ždale - gdje dobrim dijelom također ima mađarskog stanovništva, ali se ističu i značajne razlike:

„Stanovničtvo obćine Gola je gotovo sve nacionalno ispravno i orijentirano hrvatski dok je stanovničtvo obćine Ždala uglavnom već manje nacionalno čvrsto oprideljeno za Hrvatsku. Što se tiče stanovnika obćine Ždala i njihovog raspoloženja bilo bi potrebno razviti što jaču promičbu i odvraćati narod od uticaja napred spomenute mađarske promičbe. “14

Dalje dokument navodi koje bi kadrovske promjene trebalo učiniti u općini Ždala da bi se situacija promijenila u korist NDH ističući ulogu mjesnog župnika i šumara koji su slovenski kolonisti (dokument ih naziva izbjeglicama), koji su vjerojatno stigli na područje samo nakon raspada Kraljevne Jugoslavije promjenama stanovništva koje sam prije opisao. Premda se točno zna da je kotarska oblast Koprivnice unutar velike župe Bilogora igrala važnu ulogu u smještavanju preseljenog slovenskog stanovništva, trebalo bi detaljnije istražiti kolonizacijske tokove u onim naseljima oko Koprivnice i Virovitice gdje je onda živjelo veći broj Mađara, naime vanjska i unutarnja kolonizacija stanovništva također negativno utjecala na Mađare u NDH.

Kasnije (od 1943.) se glavno područje ilegalnih graničnih prijelaza između NDH i Mađarske premjestilo na područje Virovitice. To se desilo iz sasvim praktičkih razloga što se intenziviranjem partizanske djelatnosti u Slavoniji s centrom u Papuku od kraja 1942. nastala nova situacija na području između

${ }^{14}$ MVP-NDH-1942 kut br.6 Nr:7359-I-A-1942 
Drave i Save. Mađari u Slavoniji i Bilogori našli su se na geostrateški važnom položaju, na području koje se više puta za vrijeme posljednje dvije godine rata mijenjalo „vojnog gospodara“. U ovoj je situaciji Mađarska postala sigurna zemlja u blizini otkuda se često ilegalno nabavljale namirnice, streljivo i sve čega je nedostajalo u ratnim vremenima ${ }^{15}$. Tako su Mađari postali, želeći ili ne, spone ilegalne trgovine preko dvije obale Drave. Zbog promjene vlasti na ovom području često se lokalno stanovništvo, neovisno o etničkoj pripadnosti našlo u nezgodnoj situaciji. Ukoliko su zbog vojne represije jedne strane (ustaša ili partizana) pružali pomoć druga je strana smatrala njih kolaborantima. Naročito se ovo često desilo kod Mađara, koji su bili neopredijeljeni u borbi partizana i ustaša. Prema dokumentima Ozne bilo je područja gdje su ustaške vlasti još okrutniji bili sa Mađarima nego sa Srbima ${ }^{16}$. Ovo samo djelomično potvrđuju dokumenti MUP-a, naime česta su bila kršenja prava, pa čak je bilo i ubojstava Mađara ali na mogućnost etnički motiviranog ubojstva, prilikom kojeg se i MKZ uključio $^{17}$ u istragu naišao sam samo jednom među dokumentima MUP-a NDH.

Od 1943. spontano iseljenje, kako i organizirano iseljavanje Mađara s područja NDH uzet će veće razmjere prvenstveno s teritorija zauzetih od partizana kako i s područja s aktivnim vojnim djelovanjem. Tako će s područja Kutine, Humljana, Zrinske, Velikog i Malog Grđevca Mađare iseliti u ratom još nezahvaćena područja istočne Slavonije. Dok su iz Terezinog Polja, Budakovca, Daruvara, Detkovca, Đulavesa, Grubišnog Polja, Garešnice, Novog Gradaca, Rezovačke Krčevine, Velike Barne većinu mađarskog stanovništva iselili u Mađarsku”" ${ }^{\text {"18 }}$.

\section{Mađari na području pod upravom partizana (Narodnooslobodilačke vojske - NOV)}

Slično NDH, ni područja pod upravom partizana nisu bila privlačna za Mađare u Hrvatskoj. Mađari u panteonu partizanskih neprijatelja nisu bili na istaknutom mjestu, no razlika od južnoslavenskih naroda, odnos Horthyjeve

${ }^{15}$ HRHDA, 1491/OZNA 3.1 POC za Slavoniju - 087, 556/43 slika 145-146.

16 Pomoćni obavještajni centar za Slavoniju, Broj 561/43, Dana 30. prosinca 1943, Sedmodnevni izvještaj za vrijeme od 18. do 25. XII. 43. str 12. Pomoćni obavještajni centar za Slavoniju, Broj 49/44, Dana 9. I. 1944, Sedmodnevni izvještaj za vrijeme od 25. do 31. XII. 43. str. 16

${ }^{17}$ HDA, NDH MUP UMT, kut 1. 461/1942. Radi se o slučaju Jozsefa Pauške koji je bio ubijen zajedno s Milom Popovićem i Stevom Vidićem. U slučaju Pauške dokumenti utvrđuju da ubojstvo nije bilo etnički motivirano pa je odgovornima određen istražni zatvor, ali pošto se i MKZ uključio u istragu ne možemo biti sigurni da doista nije bilo etničke motivacije.

${ }^{18}$ HDA, MUP NDH, U. M. 653/1943. HDA, MUP NDH, U. M. Taj. br. 1323/1943 és U. M. 1331/43. Daljnje podatke o bježanju Mađara vidi: KARAKAŠ OBRADOV 2012: 87-105.

O pitanju izbjeglica vidi još: MILOŠEVIĆ 1981. O imovinskom pitanju izbjeglog stanovništva detaljnije vidi: A. SAJTI 1987 i A. SAJTI 2004. 
Mađarske prema komunističkoj ideologiji, naročito prema jugoslavenskom partizanskom pokretu i nacionalni (a ne internacionalni) karakter MKZ-a je već sam po sebi smjestio mađarsku nacionalnu manjinu u NDH među sumnjive društvene grupacije. U obavještajnim dokumentima Ozne u početku rata (do kraja 1943.) MKZ se pojavljuje kao neka vrsta tajne organizacije, o kojoj je malo dostupnih informacija. Čini se da se u početku Oznaa nije uspjela efikasno ugraditi u ovu organizaciju ${ }^{19}$, jer među Mađarima, kako nam dokumenti kazuju nije bilo izrazitih partizanskih simpatizera. To je svakako doprinijelo njihovoj negativnoj ocjeni sa strane partizana ${ }^{20}$. Politički su bili neutralni, ili su eventualno pripadali krugu „Mačekovaca“, no politička opredijeljenost i simpatije Mađara su se mijenjala od sela do selo, ovisno o voditeljima lokalnih zajednica, no prema NOB-u su se rjeđe neprijateljski odnosili negoli pasivno ${ }^{21}$.

Među ciljevima partizana na svojem upravnom području je najznačajniji zadatak bio uključivanje, tj. mobilizacija borbeno sposobno muškog stanovništva u svoju ratnu mašineriju. Kako u slučaju NDH, tako u slučaju NOB-a ovaj cilj se najviše kršio sa stavom mađarske zajednice. Stoga, dobar dio mađarskog stanovništva je pred partizanskim četama napustilo zauzeta područja, ne zbog veće simpatije prema NDH, nego zbog neslaganja s ciljevima Narodnooslobodilačkog pokreta. Najznačajniji dio ovog odbjeglog mađarskog stanovništva naselilo se u Mađarskoj i samo neznatan dio se vratio u poslijeratnu Jugoslaviju, naime nova vlast je i kočila povratak ovih grupa ${ }^{22}$.

Ciljevi i odnosi partizanskih postrojbi sa ne-južnoslavenskim narodima na području Jugoslavije za vrijeme Drugog svjetskog rata i nakon toga su dio i današnjih povijesnih istraživanja i rasprava. Osnovno pitanje ovih odnosa je dali je NOP već prije 1945. smatrao nužnim iseljenje, represiju, progon ili likvidaciju pojedinih zajednica ili je to postala praksa samo pri kraju rata od 1944. do 1945. Prema dokumentima Ozne primjer takvih postupaka prema kolektivnoj krivnji pojedinih zajednica se već očitovao i zimi 1943. na području naših istraživanja.

19 Obavještajci Ozne u svojim izvještajima često navode podatke - mjesto, vrijeme, nazočne - o sastancima čelnika mađarskih organizacija (najčešće lokalnih), ali nemaju informacije o tome o čemu su raspravljali i od koga primaju upute. - Poteškoće u početku organiziranja „mađarskog” partizanskog bataljona Sándor Petőfi dijelom se može objasniti time što Mađari u Hrvatskoj nisu previše simpatizirali s partizanima. (HDA OZNA 1491-03-01-02 49. str.). Nakon masovnijeg priključenja srijemskih i bačkih Mađara te simpatizera iz Mađarske bataljon će stvarno postati efikasna brigada partizanske vojske. Detaljnije vidi: ANIĆ, 2005.

${ }^{20}$ HRHDA, 1491/OZNA 3.1 POC za Slavoniju 093. 554/43. Stranice: 2, 10, 105, 113.

${ }^{21}$ Pomoćni obavještajni centar za Slavoniju, Broj 561/43, sedmodnevni izvještaj za vrijeme od 18. do 25. XII. 43. na više stranica se pojavljuju informacije vezane za mađarsku zajednicu.

22 AJ, Predsjedništvo vlade FNRJ, 35-723, 35-1032, 35-1040-1044. - navodi: KARAKAŠ OBRADOV 2012. 
„Komandir pozadinske straže u Lipovcu došao je u Ćeralije i govorio tamošnjim Švabama da će svi bez razlike biti otjerani u logor. Radi toga je nastalo veliko uznemirenje među tim Švabama i prestali su sa svakim radom, samo jedu, piju i spremaju se. Ovo je jako nezgodna pojava, jer ako se nešta mislilo protiv njih poduzeti nije im to trebalo unaprijed reći i uznemiravati ih. ${ }^{23}$

Nije se drukčije postupalo ni sa Mađarima u Moslavačkom i Bjelovarskom okrugu prilikom ulaska partizanskih postrojbi na ovo područje u rujnu 1944. Organizaciju iseljenja Mađara partizani su uzeli u svoje ruke postupajući na slijedeći način:

„... Na okruzima Moslavina i Bjelovar nastala je medju Madjarima organizacija za selenje u Madjarsku. Mi smo sa brigadom preuzeli organizaciju tog iseljavanja, a postupali smo ovako: Koji Madjari imaju nekoga u partizanima, tima ne dozvoljavamo selenje iz razloga, što bismo im morali dati i njihov imetak, kojeg bi im Švabe opljačkali i upotrijebili za rat ${ }^{24}$; oni Madjari koji imaju nekog u neprijateljskoj vojsci, proglašuju se narodnim neprijateljima $i$ iseljava ih se bez razlike dali to oni hoće ili ne. Svi muškarci sposobni za vojsku od takovih idu u konc. logor, oni pak koji nemaju nikoga ni u bandi ni kod nas, a hoće da sele, mogu da sele, ostavljajući imetak, a muškarci idu u logor; oni, koji od takovih ne će da sele, moraju poslati sposobne muškarce u NOV-u".

Tako nije čudo da se starija generacija iz Velike Pisanice na ovaj period sjeća izrekom „Ili Anti ili Titi, al kod kuće ne smeš biti! ${ }^{25}$ !”

Slična je bila situacija i u okrugu Garešnice gdje je u listopadu 1944. sustavno protjerivanje Mađara izazvalo negodovanje lokalnog hrvatskog, srpskog i češkog stanovništva, pa nisu imali povjerenja prema NOP-u i djelovanju mjesnog NOO-a. Ozna je predložila da se situacija smiri mitinzima gdje će jedan politički iskusniji drug objasniti nužnost i svrhu protjerivanja Mađara. ${ }^{26}$.

Nakon završetka rata represija prema ne-južnoslavenskim narodima se nastavljala, što nije imalo samo ciljeve etničkog karaktera (promjene etničke slike pojedinih područja) nego također nagomilavanje državne imovine putem konfiskacija. Okružne komisije za utvrđivanje ratnih zločina su osim dokazivanja zlodjela neprijatelja imala i zadatak sastavljanja inventure konfiscirane imovine prema unaprijed sastavljenom formularu. Na molbu državne komisije sastavljeno je slijedeće izvješće o Mađarima Bjelovarskog

\footnotetext{
${ }^{23}$ Pomoćni obavještajni centar za Slavoniju, Broj 563/43, Dana 22. XII 1943. Sedmodnevni izvještaj za vrijeme od 11. do 18. XI. 43. str broj 8.

${ }^{24}$ HDA OZNA za Zagrebačku oblast,1491, 4.0. br. 145/29. IX. 1944. Navodi: GEIGER Et. Al. 2006.

${ }^{25}$ Ovu izreku sam čuo od starijih mađarskih žitelja Velike Pisanice za vrijeme mojih terenskih i arhivskih istraživanja 2015.

${ }^{26}$ HDA OZNA za Kotar Garešnicu. Navodi: GEIGER Et. Al. 2006.
} 
okruga za vrijeme $\mathrm{NDH}^{27}$ koje nabraja naselja sa značajnijim mađarskim življem, odredivši im točan broj po naseljima i općinama, a potpuno negira kolektivnu krivnju Mađara, ili njihovo sudjelovanje u zločinima za vrijeme rata. Kako jedinu krivnju Mađara navodi snažno odupiranje mobilizaciji u NOV.

„Ovoj komisiji je poznato da su Mađari ovog kraja bili za vrijeme okupacije organizirani u Kulturnoj mađarskoj zajednici. Oni nisu imali u ovome kraju istaknute vođe, već su $k$ njima dolazili predstavnici mađarskog poslanstva iz Zagreba koji su im davali sva uputstva. Nedvoumno je da je većina Mađara ovoga područja bila fašistički orijentirana i oduševljavala se prvim njemačkim pobjedama. Kasnije su se neki Mađari otrijeznili i nastojali da žive u dobrim odnosima sa Hrvatima i Srbima. U krajevima oslobođenim ili kontroliranim po našim narodnim vlastima davali su Mađari sve potrebno za našu vojsku, ali odlučno su se odupirali našim mobilizacijama, čak i pod žrtvom iseljenja iz naših krajeva ili protjerivanja u radne logore. Još za vrijeme okupacije iselilo se je priličan broj Mađara u Mađarsku. Danas živi na selima malen broj Mađara, većinom onih, koji se nisu odupirali mobilizaciji NOV... Ratnih zločinaca Mađara u našem kraju nema. Može se općenito ustvrditi da Mađari ovoga kraja nisu uopće učestvovali niti u kakvom rovarenju Jugoslovenske vojske, niti u bilo kakvim progonima Srba, Židova i naprednih Hrvata... “28

Sukladno gore navedenom od 1944. Mađare su sustavno vodili u radne i koncentracijske logore. O logorima namijenjenima za Mađare nemamo informacija na području Hrvatske, ipak ćemo ih naći još i u ljeto 1945. u dokumentima i zapisima o logorima. Logor s najznačajnijim brojem Mađara vjerojatno je bio onaj u Velikoj Pisanici gdje je prema popisu 6. lipnja 1945. zajednički broj Mađara i Nijemaca bio $185^{29}$.

\section{Zaključak}

Iz prikazanih, priloženih i analiziranih dokumenata se jasno vidi da je iseljavanje Mađara koja se pripremala od vlasti NDH sustavno dovršena sa strane NOV-a. Premda se radi o dvije, u ratu suprotstavljene strane očito je da netrpeljivost prema manjinskim zajednicama (koje nisu bile politički prihvaćene ili podržane) bila srodna. U državama na prostoru bivše Jugoslavije navedena i slična događanja - zločini i zlodjela ovog perioda su i dan danas nazočni u političkom, javnom i znanstvenom diskursu (SOKCSEVITS 2016a). Mišljenja sam da ovi događaji u izgradnji nacionalnog identiteta mađarske nacionalne manjine $u$ Hrvatskoj više ne igraju važniju ulogu. Cilj nam nije bio otvoriti nova poglavlja u ovoj temi nego pridodati kolektivnom znanju o Mađarima u Hrvatskoj.

\footnotetext{
${ }^{27}$ HR DABJ 29/ 2. Okružna komisija za utvrđivanje ratnih zločina Bjelovar 4807/1945

${ }^{28}$ HR DABJ 29/ 2. Okružna komisija za utvrđivanje ratnih zločina Bjelovar 250/1945, Datum: 1945. XII. 31.

${ }^{29}$ HDA 421, 5/128, Javni tužilac okruga Bjelovar, broj: pov. 36/45. Navodi: GEIGER Et. Al. 2006: 230.
} 


\section{Literatura}

A. SAJTI E. (1987) Délvidék 1941-1944. Kossuth kiadó, 1987.

A. SAJTI E. (2004) Impériumváltások, revízió, kisebbség. Magyarok a Délvidéken 1918-947. Napvilág kiadó, 2004.

A. SAJTI E. Hungarian Minority in the Vojvodina 1918-1947. Novi Sad, 2010,

ANIĆ N. (2005) Antifašistička Hrvatska - Narodnooslobodilačka vojska i partizanski odredi Hrvatske 1941.-1945. Zagreb, 2005.

GEIGER V., RUPIĆ M., DIZDAR Z., PENAVA Š. (ed.) (2006) Partizanska i komunistička represija i zločini u Hrvatskoj 1944.-1946. Dokumenti. Slavonija, Srijem i Baranja,. Hrvatski institut za povijest - Produžnica za povijest Slavonije, Srijema i Baranje. Slavonski Brod, 2006.

JONJIĆ T. (2000) Hrvatska vanjska politika 1939.-1942. // Libar, Zagreb. 2000.

KARAKAŠ OBRADOV M. (2012) Migracija mađarskog stanovništva na Hrvatskom području tijekom drugog svjetskog rata i neposredno poslije // Tokovi Istorije, 2012/1. 87-105. DOI: 10.31212/tokovi.2012.1.kar.87-105

KASAŠ A. (1996) Mađari u Vojvodini 1941.-1946. Novi Sad, 1996. 125.

LORKOVIĆ Ml. Dr. (1939 (2005)) - Narod i zemlja Hrvata - pretisak izdanja iz 1939. Marjan tisak Doo. Split, 2005.

MILOŠEVIĆ D. Sl. (1981) Izbeglice i preseljenici na teritoriji okupirane Jugoslavije 1941-1945. // Narodna knjiga 1981.

REGAN Kr. (ed.) (2003) Hrvatski povijesni atlas. Zagreb: Leksikografski zavod Miroslav Krleža, 2003.

SOKCSEVITS D. (2016a) Viktimológia a horvát történetírásban. A bleiburgi áldozatok a horvát és nemzetközi szakirodalomban // Magyarok és szerbek a változó határ két oldalán, 1941-1948. Történelem és emlékezet Budapest: MTA Bölcsészettudományi Kutatóközpont Történettudományi Intézet, 2016. 39-53.

SOKCSEVITS D. (2016b) Hrvatska od stoljeća 7. do dana. Zagreb: Durieux, Društvo Mađarskih Znanstvenika i Umjetnika u Hrvatskoj, 2016.

Hungarian population in the Independent State of Croatia - demographic situation and the process of disappearance in the period between 1941 and 1945. Hungarians in Croatia are a minority group in the Carpathian / Pannonian Basin, compared to Hungarians from other neighboring countries, which after 1918 lost most of their members partly by emigration, partly by assimilation. The most intensive disappearances of this minority group from Croatian areas are the decades between the 1931 and 1948 censuses. In this paper, we deal with the issue of emigration and social relations of Hungarians within the borders of the Independent State of Croatia (NDH) and under the administrative area of the National Liberation Army of Yugoslavia (NOV). With the help of archival material, we try to reconstruct those social circumstances of the war years that caused the emigration of a large number of members of this community.

Keywords: Hungarians in Croatia, World War II, Independent State of Croatia NDH, National Liberation Army of Yugoslavia - NOV, emigration 


\section{Prilozi}

Br 1. Originalni dokument o broju Mađara u NDH Izvor: Državni arhiv Osijek, Fond spisa Saveza kulturno prosvjetnih društava Mađara narodne republike Hrvatske (kasnije Demokratski savez Mađara u Hrvatskoj), kutija br. 1, Opći spisi $1-609$.

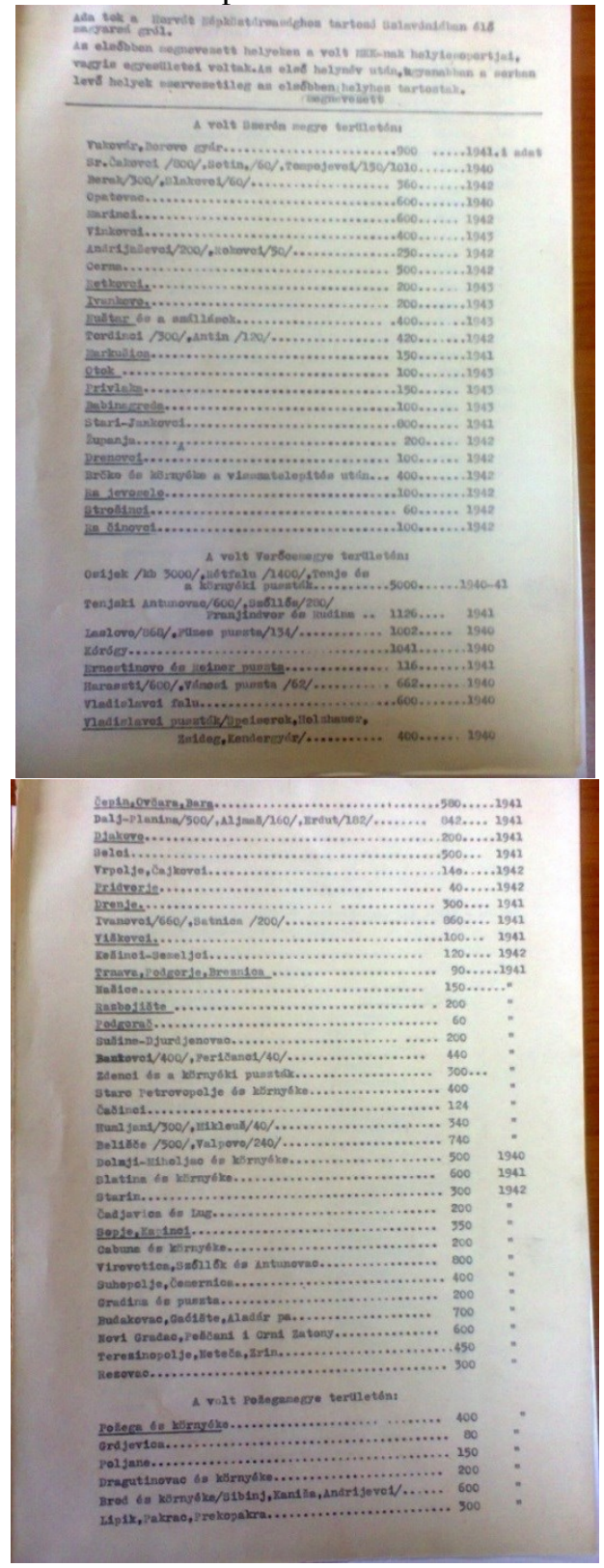




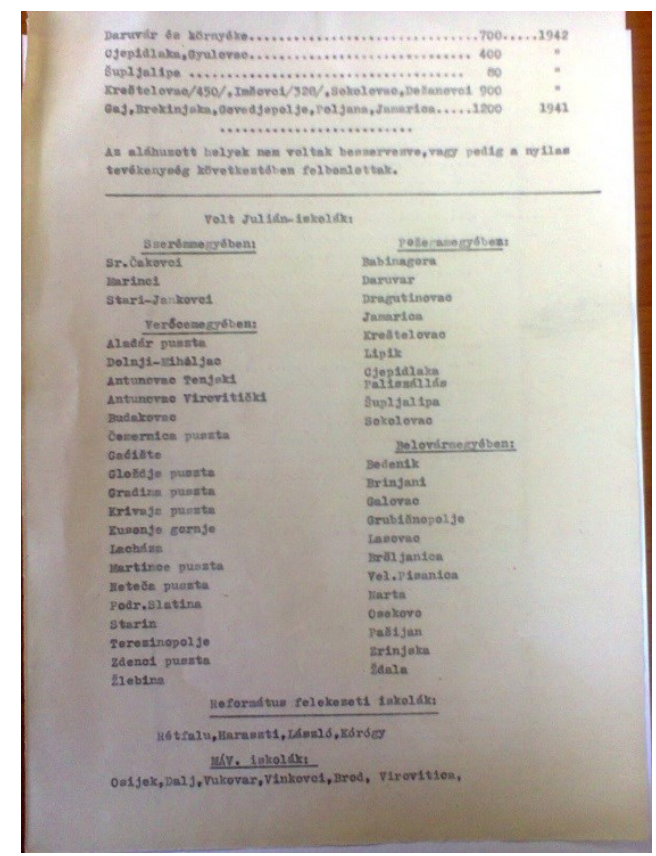

Br 2. HR DABJ 29/ 2. Okružna komisija za utvrđivanje ratnih zločina Bjelovar 250/1945, Dne: 31. prosinca 1945.

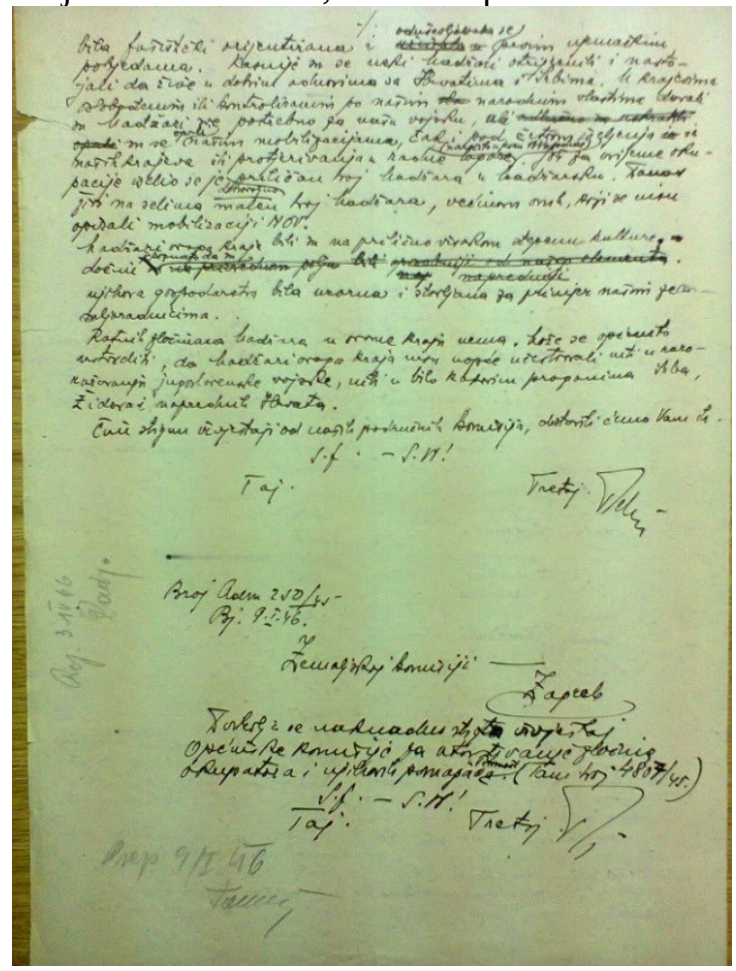


Aom . 4. 200/w

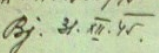

$$
\begin{aligned}
& \text { T'eualios hismecity. } \\
& \text { Tapuel }
\end{aligned}
$$

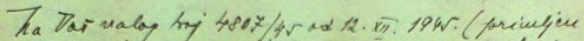

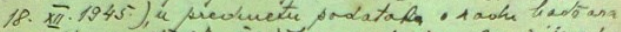

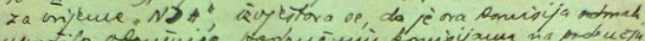

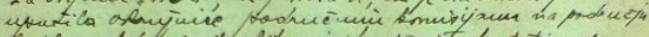

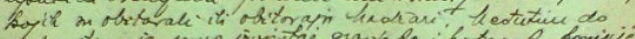

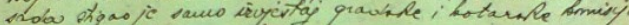

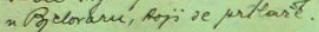

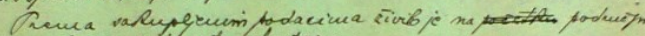

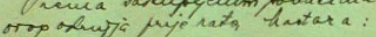

Litar Boledras 3.058

giad $\sim$

notar Carme

- Garinces

- Keforimica

ginol refrimica

lotar Yherevi

gread

$$
\text { Tutina }
$$

209

1.989

625

72

Motar Thtica

120

24

Lrega 7.865

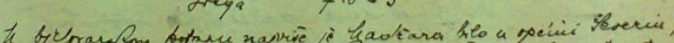

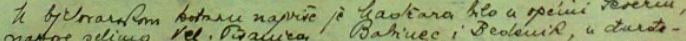

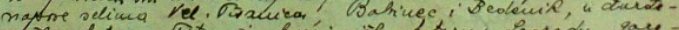

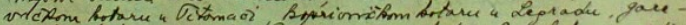

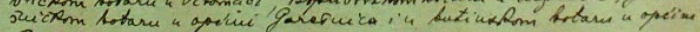

Gopraca

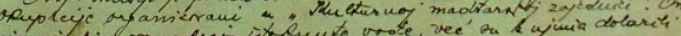

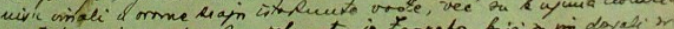

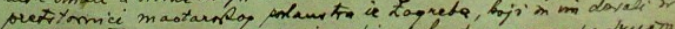

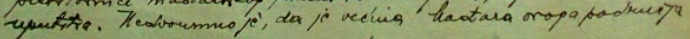

